\title{
Identification and Analysis of Urbanization and Suburbanization in Olomouc Region - Possibilities of GIS Analytical Tools
}

\author{
Jaroslav Burian and Vít Voženílek \\ Palacký University, Olomouc \\ Czech Republic
}

\section{Introduction}

In the last few years, we could see a significant increase in the importance of spatial planning as a part of the social process and development of affected regions in developed countries. It is suitable to use geospatial technologies (GIT) like geographical information system (GIS) of global positioning system (GPS) for high-quality spatial planning on the level of municipalities and regions.

Unfortunately, spatial planning sometimes strives for the best distribution of human activities at the expense of environmental conditions. However, the environmental conditions should play an essential role in the spatial planning. In practice, it often happens that new buildings are built at places unsuitable for human activities (floodplains, landslide areas), thus leading to a conflict between physic-geographic conditions and human activities both existing and proposed.

In the course of the last two centuries urbanization and suburbanization has brought about substantial changes in layouts of municipalities, concerning not only municipalities themselves but also their surroundings. Some municipalities are not prepared for the process of suburbanization and that is why many problems can appear. Without well done urban (municipality) plan, based on good quality results of spatial analysis, the city development can be chaotic and can leads to urban sprawl.

Therefore, it is extremely useful to recognize the phases of the urbanization process in due time and respond with appropriate means of municipal planning. With the help of geographical information technologies it is possible not only to recognize but also to determine, quantify, analyze or model particular phases of the urbanization process. At first this article deals with the ways and possibilities of studying the urbanization processes on a general level; further on it focuses on these processes in the Olomouc region.

\section{The process of suburbanization}

In the course of the last decades efforts have been made to come up with a theory which could describe development of municipalities within the scope of the population system. One of the most significant theories is, for instance, the concept of the differential urbanization which is 
described by Geyer and Kontuly (1993). Currently the van den Berg's theory of the stages of urban development is accepted as a general developmental model of municipalities (Ouředníček, 2000). Van den Berg (Van den Berg et al., 1982) recognizes four stages of urbanization: urbanization, suburbanization, deurbanization and reurbanization. These stages are characterized by changes in proportion of inhabitants living in municipalities and their suburbs, which is caused by different directions of population movement.

During all the stages of urban development - concurrently with the changing allocation of inhabitants - there are changes in layout and utilization of space inside urban units. This is why the stages of development of contemporary modern municipalities are characterized by changes of their inner structure.

Van den Berg (van den Berg et al., 1982) describes suburbanization as the second development stage of a city during which inhabitants move towards its outskirts. This process has greater demands for suburban space; a municipality is spatially spreading to its surroundings and also to more distant areas occupying new adjacent pieces of land. There is a population movement from inner cities to suburbias. This stage is influenced mainly by housing standards and traffic development.

Two forms of suburbanization are usually differentiated - residential and commercial (Ouředníček et al., 2008). The first one describes a settling of city outskirts by means of family housing and low-storey development (construction of satellite towns). Commercial suburbanization comprises growth of new commercial, manufacturing, storage and logistic activities. It results in moving industrial activities to less objectionable areas and creating more attractive housing localities. A new traffic infrastructure is being built and accessibility of a city centre from its suburbs is improved. Simultaneously there is an increase in mobility of labour and individual commuting to the centre of municipalities (Ouředníček, 2000).

\subsection{Demarcation of the space of the suburbanization process}

Studies of the urbanization processes indispensably require a demarcation of a centre and its suburbs - that is the area in which the particular processes take place. However, this demarcation is not unambiguous and it can be reached by number of approaches. Nowadays there is no accurate and unambiguous demarcation of urbanized and suburbanized areas.

Mostly, administrative boundaries are used during the process of demarcation of urban areas. It is first and foremost because of the easy accessibility of information for these units (Frey, 2001). This demarcation is often neither accurate nor adequate; however, regarding the accessibility and accuracy of statistical data it is frequently the only possible one.

While studying suburbanization, the administrative demarcation of a municipality against its suburbs is not as important as a morphological demarcation given by the boundaries of contiguous development (Sýkora, 2003). On the other hand, virtually all the statistical data are provided only for administrative boundaries.

For a demarcation of a municipality and its suburbs Mulíček (Mulíček, 2002) uses its administrative boundaries which more or less copy its factual boundaries demarcated by the contiguous development. In numerous municipalities the administrative boundary differs more or less substantially from the boundary demarcated by the actual contiguous 
development which is, moreover, often different from the built-up area demarcated by the municipal plan. Often there are also vast areas inside the cities which divide it into more parts and disrupt its compactness. The area between the Povel and Slavonín quarters in the southern part of the city of Olomouc can serve as a perfect example.

Suburbs of a city generally comprise of municipalities which have the most intensive relations (industrial, traffic and economical) with the city. Most often a centre and its suburbs which are connected to it by strong bonds are referred to as a functional urban area (FUA). Maier (Maier et al., 2007) state that there is no official demarcation of FUA in the Czech Republic. In their study the authors describe the demarcation of this area on the basis of the actual commuting to the centre of the settlement from the 2001 population and housing census. The decisive criterion was the limit of $25 \%$ of the economically active inhabitants commuting to the centre of the region. The municipalities which did not reach this limit but were inside the area that fulfilled the criterion were also included in the FUA.

\subsection{Localization and identification of suburbanization}

There is a substantial irregularity in disposition of both new developments and particular suburban areas (Ouředníček \& Temelová, 2008). Therefore, there is no overall, continuous growth of big cities' suburban areas; new developments are more likely to be found in suitable locations along roads, in the vicinity of bigger urban settlements with a well developed infrastructure or in more attractive locations which meet the crucial requirements for "healthy" housing within the reach of a city.

\section{AGE STRUCTURE OF EMIGRANTS FROM OLOMOUC CITY TO FUA OLOMOUC in 1991-2009}

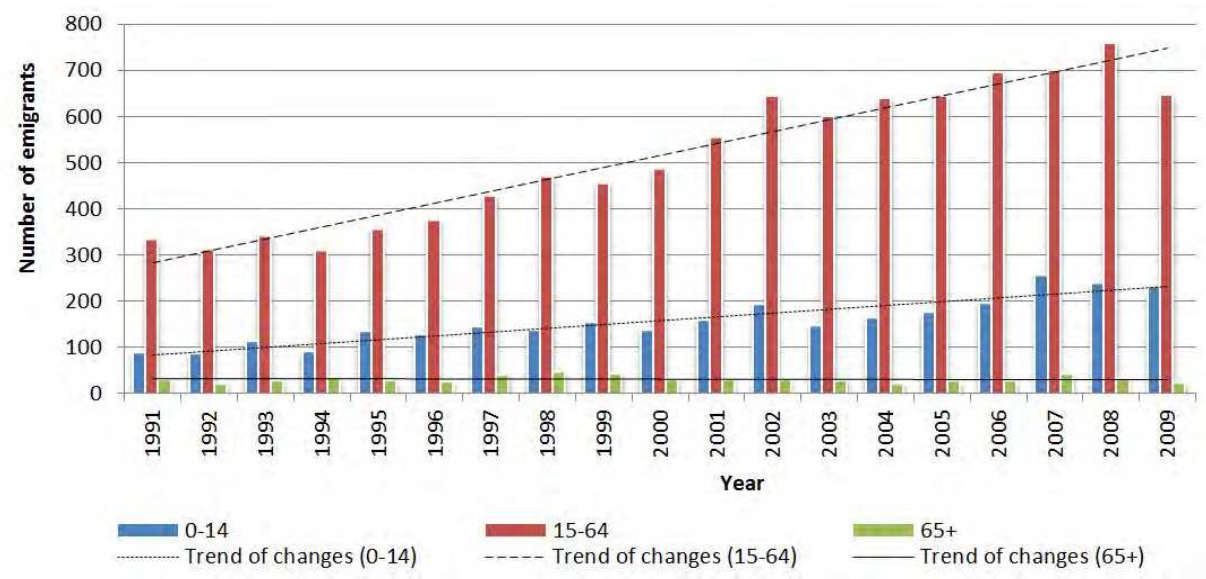

Fig. 1. Changes of the age structure caused by the suburbanization 
Suburbanization is mostly caused by moving younger, more educated people that have enough money to build house. In suburbs average age and average rate of unemployment is decreasing, number of young and more educated people is increasing. One of this phenomenon is clearly seen on the figure 1 .

Besides the suburbanization itself there is another suburban development taking place in the suburbs (suburbias - sometimes referred to as satellite towns), e.g. building activities or revitalization of economic functions (Ouředníček, 2008).

Within the boundaries of a municipality it is extremely difficult to determine whether it is suburbanization or urbanization which is taking place (Sýkora, 2003). The boundary between these two phenomena is frequently fuzzy. In case a municipality is spatially expanding as a homogenous body gradually growing along its edges, it is rather an ongoing urbanization. If, however, the development takes place in locations that are spatially separated from the so-far-urbanized areas, even though it has strong functional connections with the city, we refer to it as suburbanization. Yet in both cases the city undergoes an overall growth and spatial expansion.

\section{Studies of urbanization processes}

Sýkora (Sýkora, 2003) defines two basic approaches to the monitoring of suburbanization. The first one notices changes in spatial distribution of inhabitants based on a comparison of a core area and its periphery. The second one employs an evaluation of the selected features of the morphologic structure of metropolitan districts. From the perspective of geographical information technologies the first approach consists mainly in processing statistical data in GIS, whereas the second one relies on processing aerial or satellite photographs.

\subsection{Research by methods of GIS}

Geographic information system (GIS) is currently used for identification, description and visualization as well as for an analysis and modeling of the urbanization processes (especially urbanization and suburbanization). GIS is most frequently used to study the urbanization processes indirectly. In can be used to monitor changes of a built-up area, changes in migration and movement of inhabitants (Dobešová \& Křivka, 2011) or in the spatial distribution of cities/towns.

One of the most significant advantages of GIS is a possibility to quickly and schematically combine information about spatial properties of specific objects with their descriptive attributes (Voženílek, 2005). A subsequent visualization can, however, be dealt with in a highly inappropriate manner (more in Burian \& Št'ávová, 2009).

GIS tools in the form of analytical overlaying are used e.g. for multi-criteria decision making about an ideal utilization of an area or for a detection of changes caused by a temporal evolution of various spatial systems (Hlásný, 2007). Maantay and Ziegler (2007) introduce numerous examples of an application of GIS analytical tools for an urban environment. Other authors (Yeh \& Li, 2002) utilize cellular automata to simulate development of population density for municipal planning. Vorel (Vorel, 2006) describes cellular automata and multi-agent systems (sometimes also referred to as free-agent models) as one of the most frequently used models for urban/regional planning. In the Czech Republic it is Grill 
(Grill et al., 2008) who devoted themselves to this topic. In their article the authors describe an effort to create a model which would be capable of predicting the effects of municipal planning on the future environmental quality of areas designated for housing and commercial applications.

Significant aspects on connection land use changes, cellular automata and neural networks are described by Pechanec (Pechanec et al., 2011b). Clarke and Gaydos (Clarke \& Gaydos, 1998) describe the possibilities of connecting GIS with cellular automata to create a model which could simulate the process of growth of cities. The authors state that currently it is extremely difficult to incorporate a cellular automaton directly into the GIS environment; therefore it often stays outside this environment.

One of the possible ways to determine the urbanization processes is to employ indeterminacy (fuzzy logic). This approach is described e.g. by Krabegovic (Krabegovic et al., 2006) as exemplified by employing fuzzy logic in GIS to perform multi-criteria decision making. The most detailed account of the problems of the implementation of information systems (GIS in narrower conception) in regional/urban planning is given by Laurini (Laurini, 2001). He considers GIS to be not only a tool for professional visualization, but first and foremost a tool for processing spatial analyses, modeling, making prognoses and scenarios of regional development or multi-criteria decision making.

Laurini also stresses the importance of DSS (Decision Support Systems), i.e. tools for supporting decisions, which can be employed in regional planning in bigger territories. The issue of DSS is dealt with on a general level, e.g. in the work of Pechanec (Pechanec, 2005). More detailed description for regional planning is provided by Batty and Desham (Batty \& Desham, 1996). Hlásný (Hlásný, 2007) describes the issue of „Time GIS“ which adds the temporal dimension to the spatial one. In future, TimeGIS could be an important tool in the area of urbanism, e.g. for modeling and predicting regional development.

\subsection{Models and software for monitoring the urbanization processes}

While analyzing various natural and socio-economic systems it is highly desirable to create their simplified models - so called conceptual models which, considering the given level of abstraction, enable modeling and predicting the behavior of these systems (Hlásný, 2007).

Every model is, to a certain extent, a generalized reality. Therefore, the results provided by a model can never be on a level of actual real results. This fact has to be taken into account while using the results for various purposes (e.g. regional/urban planning). A model can never reach the complexity of a real system and this fact has to be counted on while assessing the results. If one chooses a block of buildings as the lowest resolution level, he/she can not use the results of the analysis for a smaller object (e.g. a building).

Correctly and logically made data model guarantees an effective implementation of a digital regional/municipal plan in geographic information projects (Voženílek, 2005).

Current GIS products (ArcGIS, MapInfo, GRASS) provide a wide range of analytical tools suitable for regional/municipal planning. An illustrative example of this feature is e.g. the ArcGIS extension described by Schaller (Schaller, 2007), when a regional planning of the area around Munich was administered with the help of an extensive toolbox created in Model Builder. Another ArcGIS extension is mentioned by Schaal (Schaal, 2004) who 
describes the PLANanalyst add-on. The LUCIS model (Zwick \& Carr, 2007) is a good example of a combination of GIS analytical tools into the ArcGIS extension which can be used by regional/municipal planners. Kumar and Sinha (Kumar \& Sinha, 2006) demonstrate the possibilities of the analytical tools of freeware programs. Their research employed the GRASS (Geographic Resource Analysis Support System) software as a tool for municipal planning. In their book Brail and Klosterman (Brail \& Klosterman, 2001) describe several programs which are regularly used for the needs of regional planning (chiefly in the USA but also in other parts of the world). It is for instance the METROPILUS software built as an application for the ESRI ArcView GIS software. A very similar principle is used e.g. by the INDEX software which has a vast number of functions for evaluating and planning changes in landscape. On the other hand, there are stand-alone products like TRANUS, CUF I, CUF II or CUBRA. The editors of this publication provide a series of articles focused not only on PSS (Planning Support Systems) but also on making development scenarios and simulations and, last but not least, on visualization of the results.

Furthermore, in his numerous publications (Klosterman, 1999) Klosterman describes his own software solution for making development scenarios - the What if? software tool which ranks among the PPS group (Planning Support Systems). It is also an extension of the ESRI products. A detailed description of the above mentioned models is provided by Burian (Burian, 2008). In his article he closely examines the LUCIS, LADSS, Gogracom 5W, Urban SIM, MUSE and SUDSS models and suggests a concept of an ideal scheme of the software used for urban planning. Pechanec (Pechanec et al., 2009 and Pechanec et al., 2011a) describe the LOREP model created to analyze and predict danger of floods for the needs of urban planning.

All the above mentioned models deal with the issues of urbanization on a simplified level (built-up/open areas) and do not distinguish between the particular stages of urban development.

\subsection{Statistical data for urbanization processes modeling}

One of the main manifestations of the residential suburbanization is multi-family or larger housing development in country municipalities. Therefore, a documentation of a suburbanization most frequently uses data containing numbers of constructed housing units (number of constructed housing units per 1000 inhabitants). This is often joined by another indicator - monitoring the population growth - represented by migration balance (Fig. 2). The analysis of these simple maps can bring the basic overview of urban processes in the region. The municipalities like (Hlušovice, Bystrovany, Bukovany or Dolany) with high values can be easily identify.

Description of suburbanization with the help of socio - economic data is provided in details by Stuchlíková (Stuchlíková, 2009). The author depicts the process of suburbanization in the Hradecko-Pardubická agglomeration since the 1990's till the present day in connection with the decrease of migration rates and massive housing development. This issue is also described by Ouředníček (Ouředníček, 2006) or Mulíček and Olšová (Mulíček \& Olšová, 2002). One can easily deduce that the suburbanization processes that are taking place in a number of Czech towns and cities are inconclusive and ever-changing. Stuchlíková (Stuchlíková, 2009) illustrates the manifestations of suburbanization not only with migration of population from the centre to its suburbs but she also describes the change in the age and education structure in connection with the suburban newcomers. That is to say that 
migration caused by suburbanization tends to populate suburban areas with well educated and upper income inhabitants. Virtually the same conclusion is reached also by Ouředníček (Ouředníček, 2008).

Sýkora (Sýkora, 2003) warns of certain risks connected with the use of aggregated statistical data. Such data do not cover migration of inhabitants who, for various reasons, have permanent residence in a central municipality with better and more accessible services. Moreover, not every transfer of residence (e.g. from an older house to a newer one) is a demonstration of suburbanization.

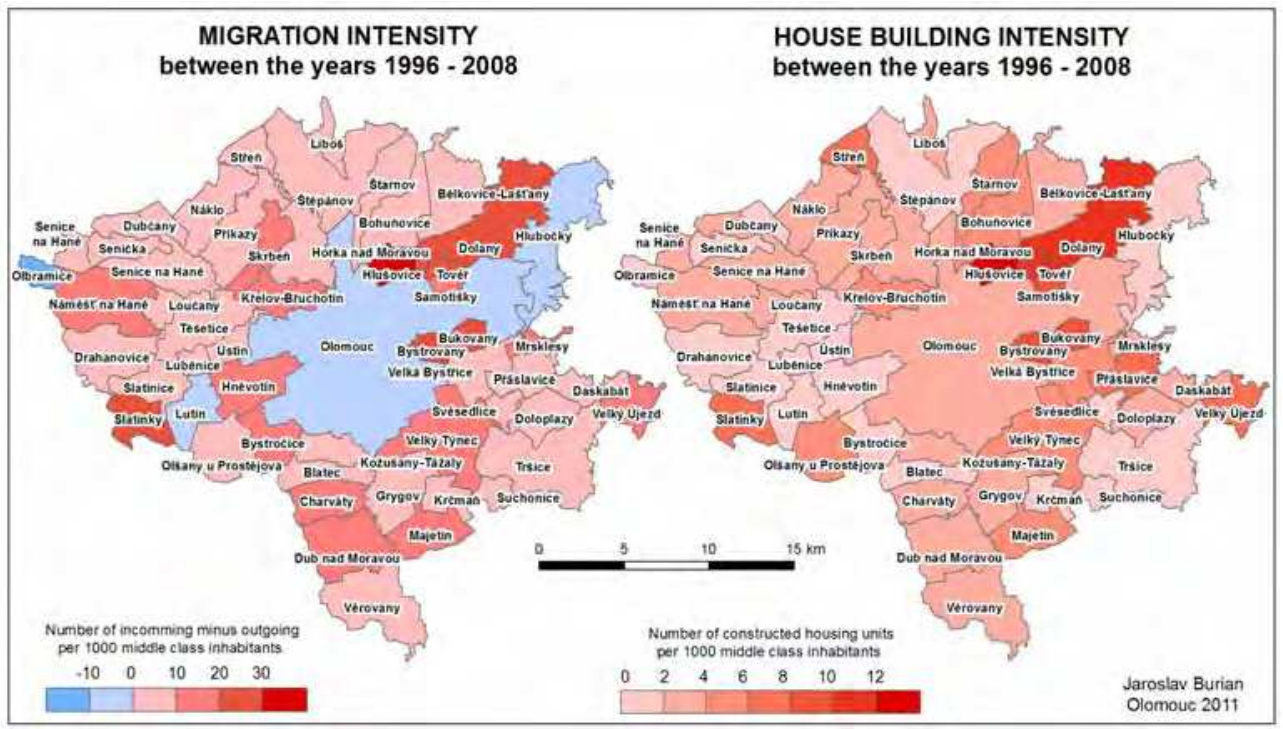

Fig. 2. Visualization of the most frequently used statistical data

In some cases only the migration of inhabitants from a central city to its suburban areas is being monitored; in others it is the general migration, not only from the centre of a municipality but also from other municipalities and parts of a state.

An absolute indicator of immigrants appears to be more appropriate for demarcating suburban areas because it takes into account the actual housing development and the sum of new suburban migrants better than a comparative indicator of net migration or its relative crude net migration rate. These indicators should rather be used for an evaluation of the intensity and spatial structure of suburbanization.

Nowadays a considerable amount of satellite towns grow on the outskirts of central municipalities and their territory lies within their administrative boundaries; therefore they are statistically almost imperceptible. In the Olomouc region we can find such an example for instance in Chomoutov, Nedvězí, Topolany, Slavonín, Droždín, Svatý Kopeček, Lošov and Radíkov. The family housing development in these areas is a typical demonstration of suburbanization. Yet these localities are former independent municipalities which are currently only quarters located within the city of Olomouc. 
Table 1 provides a brief summary of statistical indicators which the author considers to be the most important for the study of the urbanization processes. MOS data (data from the municipal statistics) are accessible annually but only for municipalities and not for basic settlement units, that would be better for detailed analysis. Census data (population and housing census) are accessible for municipalities and basic settlement units only once in a decade at the date of consensus. All data in Table 1 are available for whole Czech Republic in the same quality, same data model and are distributed online for free.

\begin{tabular}{|c|c|c|}
\hline Group & Indicator & $\begin{array}{c}\text { Data } \\
\text { source }\end{array}$ \\
\hline \multirow{3}{*}{ Demography } & Population & MOS \\
\hline & Population (citizens under 14 years of age) & MOS \\
\hline & Natural increase & MOS \\
\hline \multirow{2}{*}{ Population distribution } & Educational structure & MOS \\
\hline & Employment according to economic activity & Census \\
\hline \multirow{8}{*}{$\begin{array}{l}\text { Migration of } \\
\text { population }\end{array}$} & Immigrants & MOS \\
\hline & Emigrants & MOS \\
\hline & Net migration & MOS \\
\hline & Direction of migration & MOS \\
\hline & Cause of migration & MOS \\
\hline & Commuting to work and to school & Census \\
\hline & Commuting according to means of transport & Census \\
\hline & Commuting according to frequency & Census \\
\hline Household facilities & Ownership of a passenger vehicle & Census \\
\hline \multirow{4}{*}{ Municipal facilities } & Built-up area in Ha & MOS \\
\hline & Water-supply system & MOS \\
\hline & Sewer system & MOS \\
\hline & Gas supply & MOS \\
\hline \multirow{3}{*}{ House building } & Constructed housing units in total & MOS \\
\hline & Constructed housing units in family houses & MOS \\
\hline & $\begin{array}{l}\text { Permanently inhabited housing units } \\
\text { according to time construction }\end{array}$ & Census \\
\hline
\end{tabular}

Table 1. The most important statistical indicators for the study of the urbanization processes

\section{Analysis of the suburbanization of the Olomouc region using GIS}

A method (a conceptual model of the suburbanization intensity assessment - Fig. 3) for the modeling of the suburbanization process in the Olomouc region has been created on the basis of studying the specialized literature described in the previous chapter. From the third step this method has been implemented as a set of automatic tools for the ArcGIS software. 


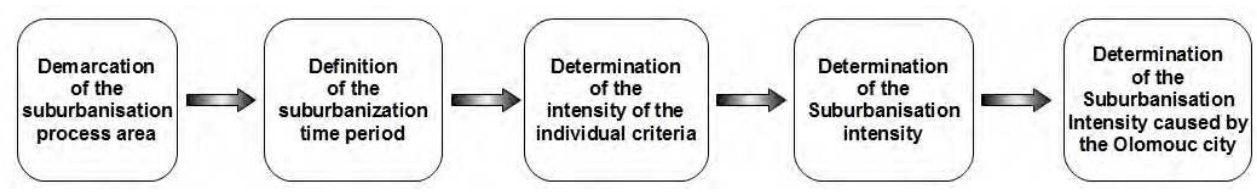

Fig. 3. Conceptual model of the suburbanization intensity assessment

The model is based on processing tabular data from the Czech Statistical Office and it employs the principle of combining vector data layers (shapefiles or other native formats of ArcGIS - Personal Geodatabase or File Geodatabase). It uses chiefly the Join (joining the tables), the Add Field (adding new attributes) and the Calculate Field operations (calculation of the intensities). It has been developed by the authors to use the ArcGIS 9.x interface in which it has been implemented as the Suburban Analyst toolbox (Fig. 4). This toolbox contains two sets of tools - Calculate Intensity and Calculate Suburbanization. The Calculate Intensity set of tools contains four independent models for partial intensities calculations (Built-up Areas Intensity, Commuting Intensity, Housing Intensity and Migration Intensity).

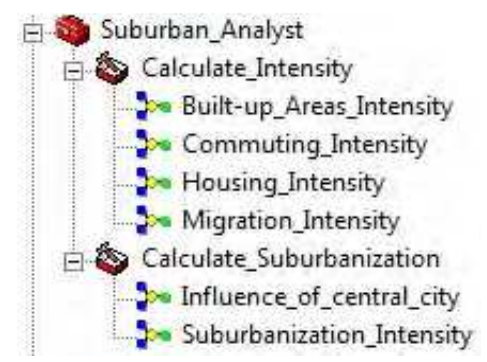

Fig. 4. The Suburban Analyst toolbox

The second set of tools (Calculate Suburbanization) contains two models. The first one (Influence Of Central City) performs the calculation of a central city's influence on suburbanization. The second model (Suburbanization Intensity) employs weighted combination of vector layers; it is an analogy of the raster operation Weighted Overlay. To make it work properly it is necessary to launch all the previous models for calculating the specific values first. The final result of the whole model is a vector layer of all the municipalities in the given area which contains the values of the suburbanization intensity during the years 1996-2008 influenced by the sum of all immigrants; furthermore, it contains the values of the suburbanization intensity in the same period influenced only by the immigrants from Olomouc.

The main advantage of this model is its intuitive graphical form (Fig. 5) which enables all the component models to be launched independently and repeatedly with the possibility of changing all the input parameters (input and output layers, attribute values, weight of particular parameters). 


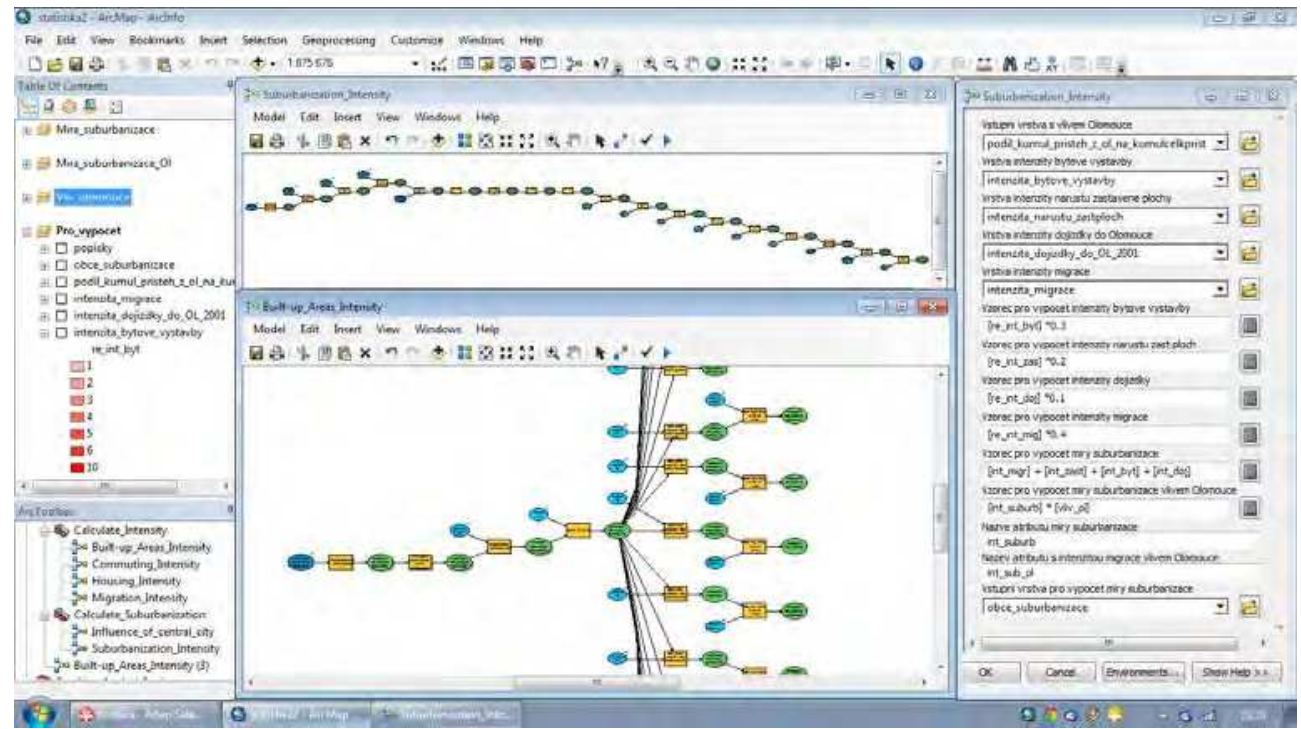

Fig. 5. Graphical interface of the ArcGIS software with Suburban Analyst Toolbox

\subsection{Demarcation of the suburbanization process area}

In the first phase the area of the process of suburbanization has been demarcated. This demarcation is most frequently performed with the help of commuting to a central city or net migration. The area is demarcated on the basis of the so-called FUA - Functional Urban Area (Maier et al., 2007). The decisive criterion in this particular research was the limit of $25 \%$ of the economically active inhabitants of a municipality commuting to the centre of the region. The municipalities which did not reach this limit but were inside the area that fulfilled the criterion were also included in the FUA. Moreover, the Hlubočky village - the only municipality in the Olomouc administrative region that was not included in the FUA - was added to the area demarcated in this manner. Regarding the fact that this village is adjacent to the city of Olomouc in the west and to the Libava military zone in the south, one can assume that it is the Olomouc city which is the most important one concerning commuting and suburbanization. The area demarcated in the previously mentioned way (FUA Olomouc+) includes the total of 53 municipalities and the city of Olomouc.

The main advantage of this model is its intuitive graphical form (Fig. 5) which enables all the component models to be launched independently and repeatedly with the possibility of changing all the input parameters (input and output layers, attribute values, weight of particular parameters). 


\section{STUDIED AREA OF SUBURBANIZATION}

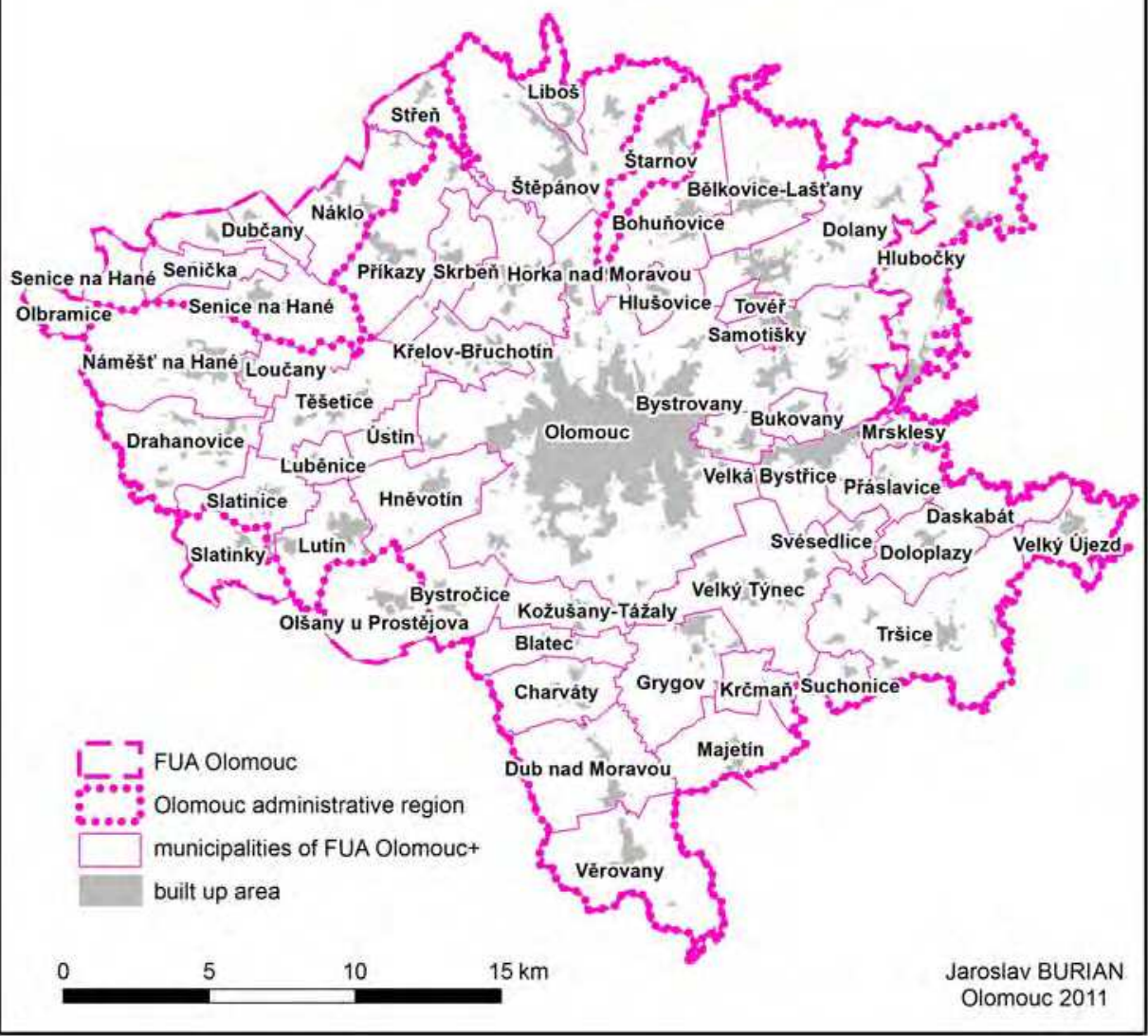

Fig. 6. Demarcation of the FUA Olomouc+ area

\subsection{Definition of the time period, during which the suburbanization takes place}

In the second phase the period during which the population of the central city (Olomouc) was decreasing because of migration was defined. This period was delimited on the basis of the ČSÚ (Czech Statistical Office) data by means of the net migration (Fig. 7). 


\section{EMIGRANTS FROM OLOMOUC CITY}

in 1991-2009
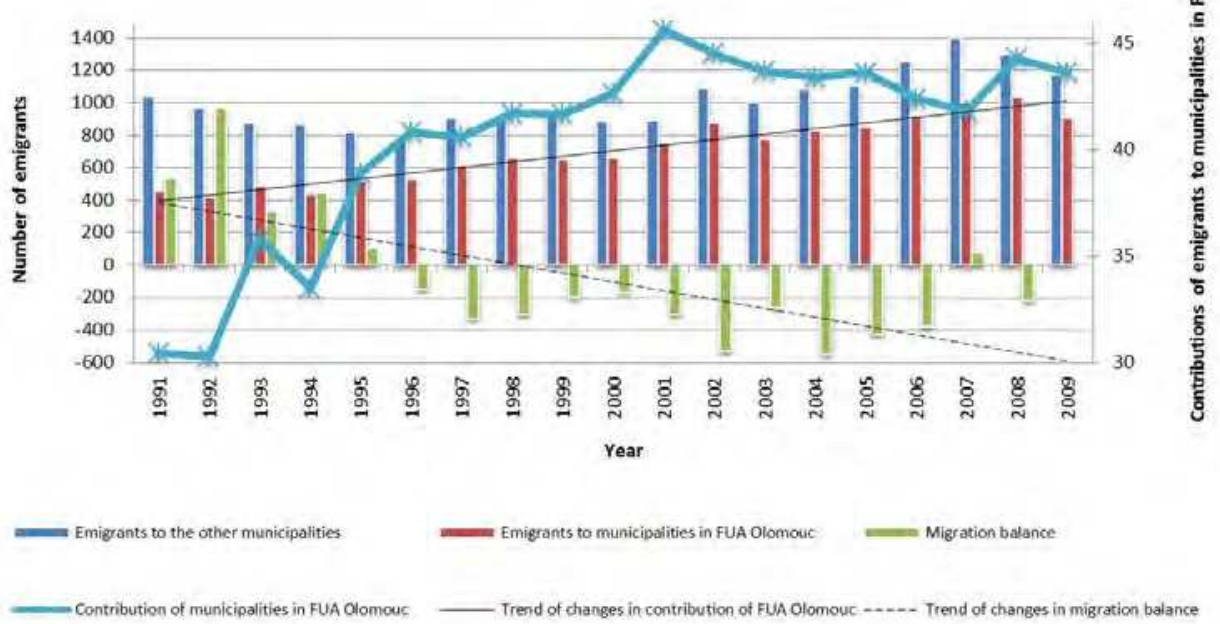

Fig. 7. Determination of the period of suburbanization

CHANGES IN NUMBER OF INHABITANTS IN OLOMOUC CITY AND FUA OLOMOUC in 1991-2008

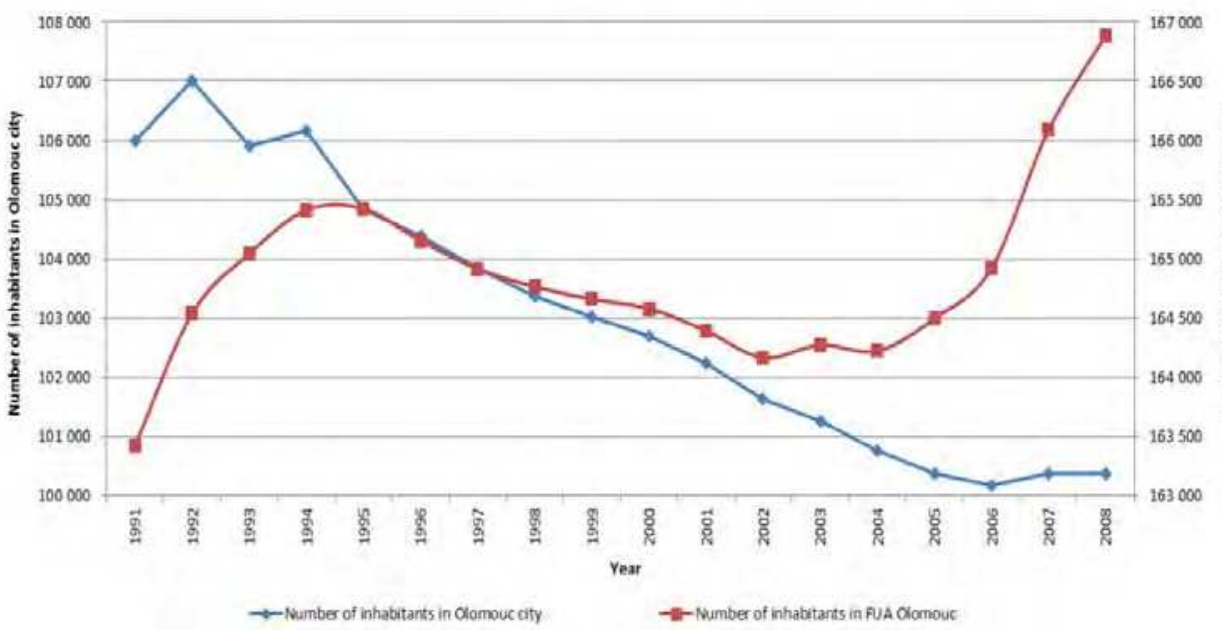

Fig. 8. Comparison of the population of the city of Olomouc and the FUA Olomouc+ 
As the development trend clearly shows, since 1991 the net migration has had a steady downward tendency and since 1996 till 2008 it had a negative value (within the range of 150 to -550$)$ with the exception of 2007 when the net migration reached positive values $(+78)$. The Cumulative net migration from the period between the years 1996 and 2008 is -3746 . As the figure 8 clearly shows it is a period during which the city of Olomouc was losing inhabitants whereas the whole region (FUA Olomouc + ) was gaining them rapidly.

This period was designated as the time during which an emigration of inhabitants occurred and the process of suburbanization is very likely to occur. Therefore, in the other parts of the model the data from the years 1996-2008 are dealt with.

\subsection{Determination of the intensity of the individual criteria}

The criteria used to determine the intensity of suburbanization by means of the constructed model were chosen on the basis of the study of specialized literature introducing these criteria as the most significant for studying the urbanization processes. More specific selection was based on multi-criteria decision analysis.

The methods of geometrical mean, Fuller's rectangle and Saaty method of pair comparison were used (Saaty, 1983). All methods are commonly used in statistics and multi-criteria analysis but in area of geography and urbanism are not so known. All of them are based on comparison all criteria, Saaty method allows to set up not only difference between criteria but also level of these differences. These methods are well described in many papers or books about multi criteria evaluation (Saaty, 1983 or Keeney, 1992). Almost it is not possible to select the most suitable method of evaluation. That is why the results of three most significant methods were used and compared. The final result of selection criteria was based on Saaty method, criteria with value lower than 0,1 were eliminated and the only 4 criteria left. Those were evaluated and compared once again and final values on intensities were estimated.

Even though absolute values (number of constructed housing units or number of immigrants) advert to a possible process of suburbanization, they can not be used to determine the level of suburbanization. Whereas a construction of 20 family houses in a municipality with the population of 5000 can be almost insignificant, in a municipality with 200 inhabitants it suggests a far more accentuated process of urbanization. This is a reason all the selected criteria were converted into their relative values (per 1000 inhabitants) so that they could be compared and evaluated together. Because of the subsequent computer processing (weighting of the layers and their summarization) the resulting relative values of every particular criterion were reclassified to new values within the range of $0-10$. In case of the housing development intensity and the migration intensity the original values were negative; therefore also the reclassified values are negative.

The criteria used to determine the level of suburbanization:

- Migration intensity (crude migration rate) - the average value of net migration per 1000 middle class inhabitants between the years 1996-2008,

- Intensity of increase in built-up area - the average value of increase in built-up area per area of the municipality,

- Intensity of house building - the average value of increase in number of constructed housing units per 1000 middle class inhabitants between the years 1996-2008, 
- Intensity of commuting to Olomouc - the number of job and school commuters to Olomouc per 1000 middle class inhabitants between the years 1996-2008,

\subsection{Determination of the Suburbanization Intensity}

Computer model „Suburban Analyst"realizes calculation of all mentioned relative criteria and allows estimating intensity of suburbanization. The constructed computer model executes the following proposed method to determine the suburbanization intensity (Fig. 9).

To calculate the suburbanization intensity it was necessary to define the weight of the individual criteria first. The weights were estimated by multi-criteria analysis, based on Saaty method.

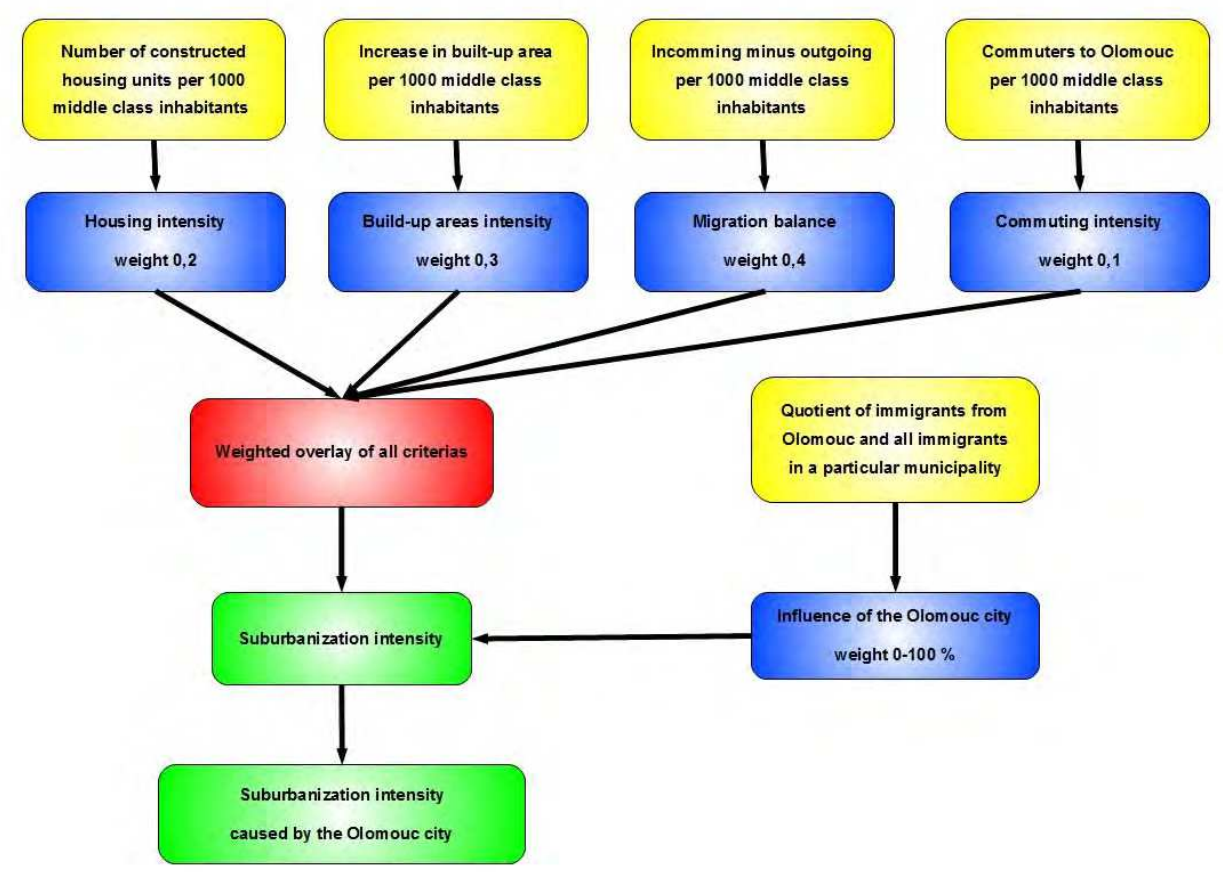

Fig. 9. The schematic method to determine the suburbanization intensity

The migration intensity with the weight of 0,4 was designated as the most significant criterion, which is usually the basic starting point of the process of suburbanization. Furthermore, the intensity of house building $(0,2)$, the intensity of commuting to Olomouc $(0,1)$ and the intensity of increase in built-up area $(0,3)$ were designated. First these weights are used in the model to multiply all four reclassified intensities which are subsequently summarized. In this way the suburbanization intensity was calculated for every municipality and listed in a newly created attribute. Within the frame of the model it is possible to change the individual weights and carry out the whole calculation repeatedly. 


\subsection{Determination of the suburbanization intensity caused by the city of Olomouc}

Suburbanization is characterized by the migration of inhabitants from a city to its suburbs. However, in a number of specialized publications suburbanization is also used to refer to the process of migration from other parts of a state to the suburbs of the monitored city. The constructed model carries out all calculations using data which encompass the influence of the whole state. Therefore, in the last step the final values of the suburbanization intensity were multiplied by the values of the level of influence of Olomouc. This level has been defined as a quotient of the cumulative number of immigrants from Olomouc and the cumulative number of all immigrants in a particular municipality in the period of 19962008. The resulting quotient is depicted in the Figure 7 together with the development trend; here it is fairly apparent that since 1996, when the city of Olomouc had a negative net migration, it has always assumed values higher than $40 \%$. The values of the quotient for the Olomouc+ FUA range from the minimum values of $30 \%$ (the municipalities of Střen, Olbramice, Slatinky, Štranov, Velký újezd) to the maximum values of 80 \% (Bukovany, Skrbeň, Ústín, Tovéř, Hněvotín, Hlušovice).

\section{The suburbanization of the Olomouc region}

Ptáček (Ptáček et al., 2007) state that the development of the residential functions outside the city limits has been taking place gradually since 1997; this development concerned the localities within the accessibility zone of $10 \mathrm{~km}$ (15-20 minutes). Furthermore, the authors claim that the localities undergoing the most intensive development during this period of time were Dolany, Slušovice, and Křelov. They demarcate the administrative boundary of the city of Olomouc as an area in which it is possible to identify various intensities of e.g. the process of suburbanization in 21 municipalities. House building in this area (both in the city and its suburbs) manifested itself most significantly in the second half of the 1990s.

On the basis of the results provided by the Suburban Analyst model it is possible to agree with the conclusions of these authors and elaborate on them. The results of the model are shown on the figure 10 .

According to the results of model "Suburban Analyst" is possible to delimited 21 municipalities with intensity of suburbanization higher then average value $(2,13)$ and 25 municipalities with intensity of suburbanization higher then median $(1,9)$. When the influence of all municipalities in the Czech Republic is taken into account the intensity of suburbanization reaches its peak in Hlušovice $(7,3)$, Bystrovany $(7,2)$, Dolany $(4,7)$, Bukovany $(4,4)$, Tovéř $(4,2)$, Samotišky $(4,2)$, Velký Týnec $(4,2)$ and Mrsklesy $(4,1)$. Those municipalities are characteristic by the massive housing activities that can be easily documented by photos (fig. 12). These municipalities are followed by the municipalities of Křelov-Břuchotín, Hněvotín, Slatinky, Velký Újezd, Bohuňovice and Majetín.

When only the influence of Olomouc is taken into account the order of the municipalities stays almost the same; the only difference being lower final values: Hlušovice $(5,3)$, Bystrovany (5), Bukovany (3,8), Tovéř $(3,3)$, Samotišky (3), Dolany $(2,9)$, Hněvotín $(2,7)$, Křelov-Břuchotín $(2,6)$, a Velký Týnec $(2,5)$. The value of suburbanization intensity is higher than average value $(1,23)$ in 23 municipalities and higher than median $(1,9)$ in 26 municipalities. Correlation coefficient was calculated for each municipality and its average value $(0,96)$ shows the strong cohesion between both values of suburbanization. 


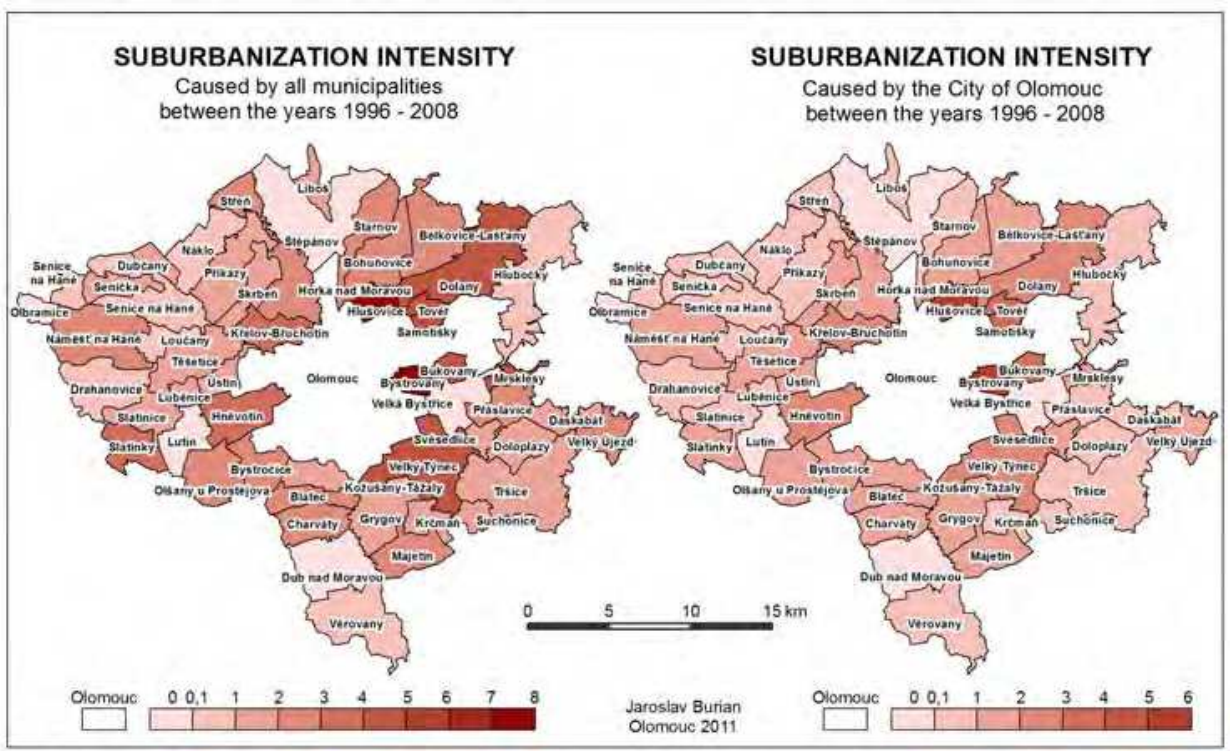

Fig. 10. Visualization of the model's results

The only exception can be seen in some specific municipalities. These municipalities are, rather naturally, in the close vicinity of Olomouc, whereas in the previous case (suburbanization influenced by all municipalities in ČR) some of the municipalities with considerable suburbanization intensity are more distant (e.g. Slatinky, Majetín or Velký Újezd). These are the localities attractiveness of which does not influence only Olomouc. The municipality which stands out the most from the results achieved is Hlušovice - probably the most typical example of a satellite town, population of which more than doubled between the years 1996 and 2008 (Fig. 11).

Ptáček and Szczyrba (Ptáček \& Szczyrba, 2004) state that the most pronounced house building in the suburbs of the city is concentrated in the north and northeast; peripheral parts of the city are being developed mostly in the south and southeast. However, currently the municipalities in the northeast of the city are beginning to reach their capacity and their potential for further development is insignificant. This fact is responded to by the increased intensity of house building in other directions (e.g. Hněvotín in the west or Majetín and Charváty in the south of the city of Olomouc).

The model results can be evaluated with respect to the valid municipality plans. In municipalities with higher value of the suburbanization intensity are all planned areas for housing used and new houses are or have been built. In these municipalities the new plans are not prepared or no next development is suggested (Hlušovice, Bukovany, Bystrovany). This situation, described as relative saturation leads to increasing intensity of housing in various parts of Olomouc region. The new houses are built in municipalities that have enough areas for housing suggested by the municipality plan (Hněvotín, Bystročice, Majetín and Charváty). 


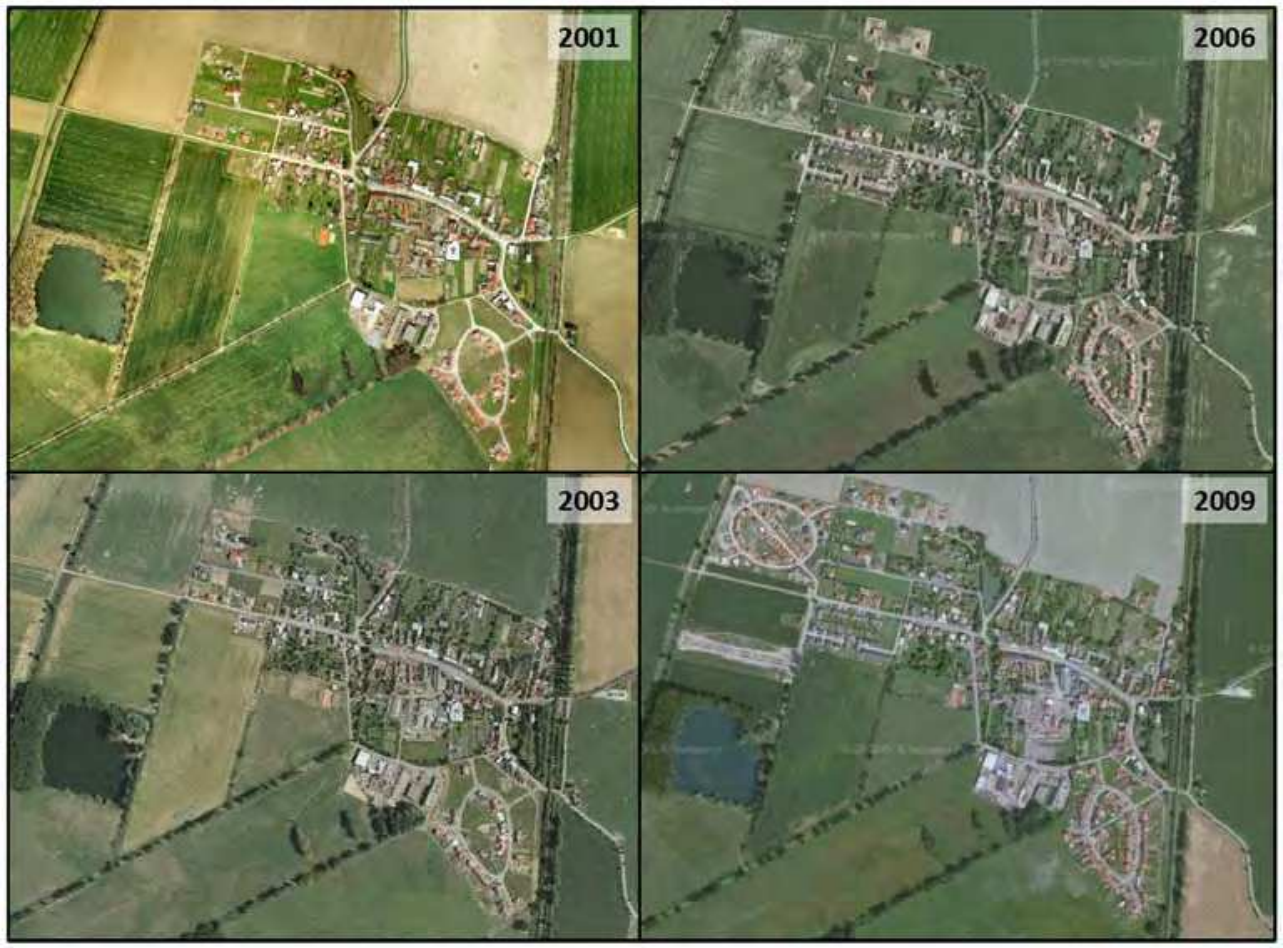

Fig. 11. Example of suburbanization observation based on aerial photographs

All results of all analysis were evaluated by terrain survey. All areas of new housing in studied municipalities were documented by photos (fig. 12) and also all coordinates were stored by using GPS. For selected municipalities, examples of urban development caused by suburbanization were created by using aerial photographs from different ages (fig. 11).

From the above mentioned findings it follows that the process of the development of new residential localities in the suburban zone of Olomouc has just started (Ptáček \& Szczyrba, 2004). In the following period, which is till 2008, more pronounced manifestations of this process took place in a number of other municipalities and with different intensity too. So far there are no statistical data for the period since 2008; however, on the basis of the development trend of suburbanization in the individual municipalities one can assume that this process will go on. According to relative saturation is possible to expect process of suburbanization in municipalities that serve in its municipality plans enough areas for housing. As a good example can be mentioned Tršice (local part Hostkovice) where 40 new houses are going to build in 2011. 

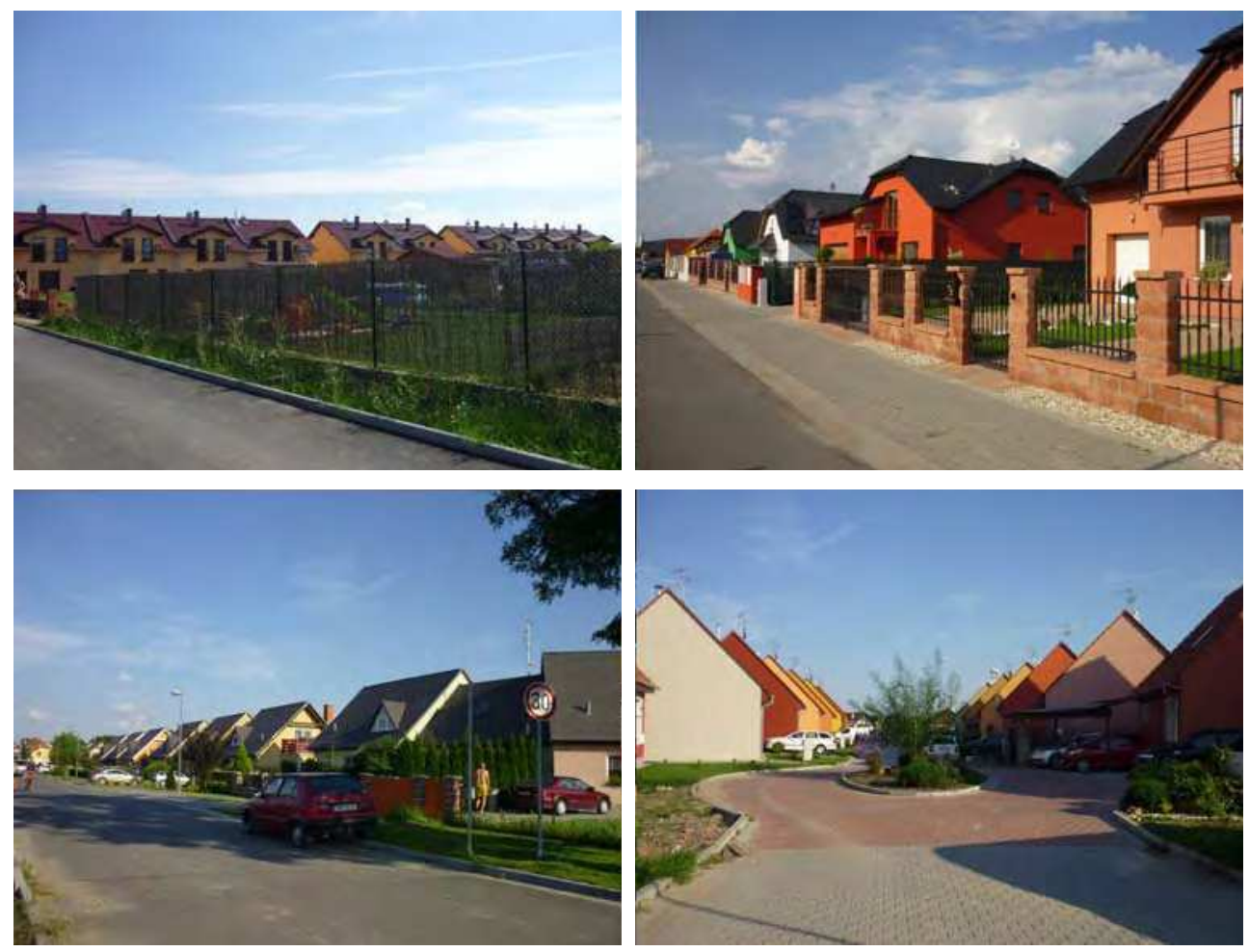

Fig. 12. Residential suburbanization in municipalities of FUA Olomouc +

\section{Conclusion}

Suburbanization and its manifestations are being studied and elaborated on from various perspectives by number of specialists. Quantification of this phenomenon is not so frequent an approach; however, in the GIS environment its solution is not only possible but also relatively easy. The constructed computer model and the subsequent results can serve as an example of a possible utilization of GIS for quantification and objectification of the study of the urbanization processes The Suburban Analyst model employs aggregated statistical data which are considered to be optimal for the study of suburbanization by most of the specialists.

The model uses multi-criteria analysis and weighted overlaying of vector layers to determine final values of suburbanization intensity. Selected criteria were chosen by multicriteria evaluation an can be considered as a objective. Pre-selection of criteria was based on various references describe urban processes. The whole process was consulted with experts - urban planners and geographers from Office of urban planning of Olomouc city and from Office of urban planning of Regional District of Olomouc city

Created model Suburban Analyst and calculated values of suburbanization intensity are one of the first approaches to quantification of urban processes by using statistical data and GIS software. According to the terrain survey and strong cohesion of the results with new housing can be the results of the model considered as relevant. 
With regard to a slightly different understanding of the term suburbanization (an influence of immigrants from a central city only or an influence of immigrants from all municipalities in a given state) there are two types of results or resulting intensities. Therefore, it is necessary to provide them with an appropriate comment.

Simulation and modeling of the urbanization processes can serve as a useful approach to the understanding of the consequences of the contemporary politics of regional planning, thus providing a possibility to predict development of a region and its impact on sustainable growth.

The analysis of urban processes by estimation of intensity of suburbanization can show significant approach to study of contemporary policy of urban planning and trends of citizen movement. The results can help to predict possible future development of the Olomouc region and to predict impact of decision system of Czech urban planning.

\section{Acknowledgment}

This article is a part of the "Research of the citizen movement between urban and suburban space of the Olomouc region" project (number of project PrF_2010_14) with the aid of the Inner Grant Competition of the Palacký University in Olomouc.

\section{References}

Batty, M. \& Densham, P. J. (1996). Decision support, GIS, and urban planning, In: Sistema terra, 15. 08. 2011, Available from:

< http://www.acturban.org/biennial/doc_planners/decission_gis_planning.htm>

Berg, L. van den; Drewet, R. ; Klaasen, L. H. ; Rossi, A.; Vijverberg, C. H. T. (1982). A Study of Growth and Decline, Pergamon Press, Oxford, New York, Totonto, Sydney, Paris, Frankfurt

Brail, R. K. \& Klosterman, R. E. (2001). Planning Support Systems, ESRI Press, ISBN 978-15894-8011-7, Redlands, USA

Burian, J. (2008). GIS analytical tools for planning and management of urban proceses, Proceedings of GIS Ostrava 2008, pp. 13, ISBN 987-80-254-1340-1, Ostrava, Czech Republic, January, 2008

Burian, J. \& Štávová, Z. (2009). Kartografické a geoinformatické chyby v územních plánech. Geografie - Sborník ČGS, Vol. 114, No. 3, (2009), pp. (179-191), ISSN 1212-0014

Burian, J. et al. (2010). Development of Olomouc city in 1930 - 2009: based on analysis of functional areas. Palacký University in Olomouc, ISBN 978-80-244-2698-3, Olomouc, Czech Republic

Burian, J.; Miřijovský, J.; Macková, M. (2011b). Suburbanizace Olomouce, Urbanismus a územní rozvoj, Vol. 14, (in print), ISSN 1212-0855

Clarke, K. C. \& Gaydos, L. J. (1998). Loose-coupling a cellular automaton model and GIS. Geographical informatik science, 7, (12), 699-714.

Dobesova, Z. \& Krivka, T. (2011), Walkability index in the urban planning: A case study in Olomouc city, Urban Planning, InTech, ISBN 979-953-307-412-1

Frey, W. H. \& Zimmer, Z. (2001). Defining the City, In: Handbook of Urban Studies, Paddison, R. et al., pp. 14-36, Sage, ISBN 978-08-039-7695-5, London, Great Britain 
Geyer, H. S. \& Kontuly, T. M. (1993). A Theoretical Foundation for the Concept of Differential Urbanization, In: Differential Urbanization: Integrating Spatial Models, Geyer, H. S. \& Kontuly, T. M., pp. 290-308, ISBN 978-03-406-6285-4, Arnold, London, Great Britain

Grill, S. ; Vorel, J. ; Maier, K. ; Čtyroký, J. ; Drda, F. (2008). Simulation and assessement model of urban development, Proceedings of GIS Ostrava 2008, pp. 11, ISBN 987-80254-1340-1, Ostrava, Czech Republic, January, 2008

Heisig, J.; Burian, J.; Miřijovský, J. (2011). Změny intenzity osobní automobilové dopravy a vliv na prostorovou diferenciaci suburbanizace, Perner's Contacts. Vol. 6, No. 1, (April 20011), pp. (431-450), ISSN 1801-674X

Hlásný, T. (2007). Geografické informačné systémy - Priestorové analýzy, Zephyros\&Národné lesnické centrum - Lesnický výzkumný ústav Zvolen, ISBN 978-80-8093-029-5, Banská Bystrica, Slovakia

Johnson, R. J. ; Gregory, D. ; Pratt, G. ; Watts, M. (2000). The Dictionary of Human Geography, Blackwell Publishers, ISBN 978-06-312-0561-6, Oxford, Great Britain

Karabegovic, A.; Avdagic, Z.; Ponjavic, M. (2006). Applications of Fuzzy Logic in Geographic Information Systems for Multiple Criteria Decision Making, Proceedings of CORP 2006 - 11th International Conference on Urban Planning \& Regional Development in the Information Society, pp. 235-244, ISBN 978-39-502-1390-4, Vienna, Austria, May 2006

Keeney, R. L. (1992). Value focused thinking: A path to creative decisionmaking, Harvard University Press., ISBN 978-06-749-3198-5, Cambridge, England

Klostermann, R. E. (1999). What-If? Collaborative Planning Support System. Environment and Planning B: Planning and Design, Vol. 26, No. 3, (1999), pp. (393-408), ISSN 0265-8135

Kumar, V. R. ; Satya, A. V.; Sinha, P. K. (2006). Urban Planning with Free and Open Source Geographic Information system. Geological Survey of India, Southern Region, Hyderabad, No. 1, (2006), pp. (393-408)

Laurini, R. (2001). Information Systems for Urban Planning, CRC Press, ISBN 978-07-484-09631 , London and New York

Maantay, J. \& Ziegler, J. (2007). GIS for the Urban Environment, ESRI Press, ISBN 978-15-8948082-7, Redlands, USA

Maier, K. ; Drda, F. ; Mulíček, O. ; Sýkora. L. (2007). Dopravní dostupnost funkčních městských regionů a urbanizovaných zón v České republice. Urbanismus a územní rozvoj, Vol. 10, No. 3, (May 2007), pp. (75-80), ISSN 1212-0855

Mulíček, O. \& Olšová, I. (2002). Město Brno a důsledky různých forem urbanizace. Urbanismus a územní rozvoj, Vol. 5, No. 6, (December 2002), pp. (17-20), ISSN 12120855

Ouředníček, M. (2002). Suburbanizace v kontextu urbanizačního procesu, In: Suburbanizace a její sociální, ekonomické a ekologické důsledky, Sýkora, L., pp. 39-54, ISBN 978-80-9019149-5, Ústav pro ekopolitiku, Praha, Czech Republic

Ouředníček, M. (2000). Teorie stádií vývoje měst a diferenciální urbanizace, Sborník ČGS, Vol. 105, No. 4, (2000), pp. (361-369), ISSN 1212-0014

Ouředníček, M. et al. (2008). Suburbanizace, In: Suburbanizace, 20. 7. 2011, Available from: 
<http:/ / www.suburbanizace.cz>

Ouředníček, M. \& Temelová, J. (2008). Současná česká suburbanizace a její důsledky. Veřejná správa, Vol. 11, No. 4, pp. (1-4), ISSN 1213-6581

Pászto, V.; Tuček, P.; Marek, L.; Kuprová, L.; Burian, J. (2010) Statistical inferences - visualization possibilities and fuzzy approach computing, In: Advances in Geoinformation Technologies 2010, Horák, J., pp. (163-178), ISBN 978-80-248-2357-7, VŠB - Technical University of Ostrava, Ostrava, Czech Republic

Pechanec, V. (2006). Nástroje pro podporu rozhodování v GIS, Palacký University in Olomouc, ISBN 80-244-1553-4, Olomouc, Czech Republic

Pechanec, V.; Burian, J.; Kilianová, H.; Štávová, Z.(2009). Analysis and prediction of flood hazards in urban planning, Proceedings of Cartography and Geoinformatics for Early Warning and Emergency Management: Towards Better Solutions, pp. 493-500, ISBN 97880-210-4796-9, Prague, Czech Republic, January, 2009

Pechanec, V.; Burian, J.; Kilianová, H.; Němcová, Z. (2011a). Geospatial analysis of the spatial conflicts of flood hazard, Moravian Geographical Reports. Vol. 19, No. 1, (March 2011), pp. (11-19), ISSN 1210-8812

Pechanec, V.; Dobešová, Z.; Burian, J. (2011b). Neural networks and cellular automata in modelling land use changes, Neural Network World, Vol. 21, No. 4, (in print), pp. (127), ISSN 1210-0552

Ptáček, P. ; Szczyrba, Z. ; Fňukal, M. (2007). Proměny prostorové struktury města Olomouce s důrazem na rezidenční funkce, Urbanismus a územní rozvoj, Vol. 10, No. 2, (March 2007), pp. (19-26), ISSN 1212-0855

Ptáček, P. \& Szczyrba, Z. (2004). Olomouc - profil města s identifikací problémů spojených se suburbanizací. In: Krize měst z neregulovaného růstu, Gremlica, T., pp. 23, Ústav pro ekopolitiku, Prague, Czech Republic

Pulselli R. M. \& Ratti C. (2005). Mobile Landscapes, Equilbri , Il Mulino, Italy

Saaty, Th. L. (1983). Priority Setting in Complex Problems, Proceedings of the Fifth International Conference on Multiple Criteria Decision Making, pp. 326 - 336, Berlin/Heidelberg/New York, 1983

Schaal, P. (2004). Landscape planning and GIS-based data management. Proceedings of ESRI-International UC, pp. 8, San Diego, USA, 2004

Schaller, J. (2007). ArcGIS - ModelBuilder Applications for Regional and Development Planning in the Region of Munich (Bavaria), Proceedings of 16. konference GIS ESRI a Leica Geosystems v ČR, pp. 1, ISBN 978-80-254-0299-3, Praha, Czech Republic, January, 2007

Stuchlíková, M. (2009). Hradecko-pardubická aglomerace - socioekonomické podmínky, Proceedings of seminar AUÚP, pp. 58-62, ISBN 978-80-87318-03-4, Brno, Czech Republic, May 2009

Sýkora, L. (2003). Suburbanizace a její společenské důsledky, Sociologický časopis, Praha. Vol. 39, No. 2, (2003), pp. (217-233), ISSN 0038-0288

Vorel, J. (2006). Informace o urbánním prostředi, jejich konceptualizace a komunikace, Fakulta architektury ČVUT v Praze, Praha, Czech Republic 
Voženílek, V. (2005). Cartography for GIS - geovisualization and map communication, Palacký University in Olomouc, ISBN 80-244-1047-8, Olomouc, Czech Republic

Yeh, A. G. \& Li, X. (2002). A cellular automata model to simulate development density for urban planning, Environment and Planning B: Planning and Design, Vol. 29, No. 1, (2002), pp. (431-450), ISSN ISSN 0265-8135

Zwick, P. \& Carr, M. (2007). Smart Land-Use Analysis, The LUCIS Model, ESRI Press, ISBN 978-1-58948-174-9, Redlands, USA 


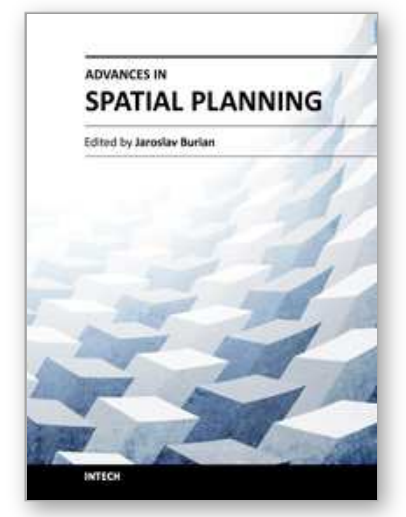

\author{
Advances in Spatial Planning \\ Edited by Dr Jaroslav Burian
}

ISBN 978-953-51-0377-6

Hard cover, 366 pages

Publisher InTech

Published online 21, March, 2012

Published in print edition March, 2012

Spatial planning is a significant part of geosciences that is developing very rapidly. Many new methods and modeling techniques like GIS (Geographical Information Systems), GPS (Global Positioning Systems) or remote sensing techniques have been developed and applied in various aspects of spatial planning. The chapters collected in this book present an excellent profile of the current state of theories, data, analysis methods and modeling techniques used in several case studies. The book is divided into three main parts (Theoretical aspects of spatial planning, Quantitative and computer spatial planning methods and Practical applications of spatial planning) that cover the latest advances in urban, city and spatial planning. The book also shows different aspects of spatial planning and different approaches to case studies in several countries.

\title{
How to reference
}

In order to correctly reference this scholarly work, feel free to copy and paste the following:

Jaroslav Burian and Vít Voženílek (2012). Identification and Analysis of Urbanization and Suburbanization in Olomouc Region - Possibilities of GIS Analytical Tools, Advances in Spatial Planning, Dr Jaroslav Burian (Ed.), ISBN: 978-953-51-0377-6, InTech, Available from: http://www.intechopen.com/books/advances-in-spatialplanning/identification-and-analysis-of-urbanization-and-suburbanization-in-olomouce-region-possibilities-of-

\section{INTECH}

open science | open minds

\section{InTech Europe}

University Campus STeP Ri

Slavka Krautzeka 83/A

51000 Rijeka, Croatia

Phone: +385 (51) 770447

Fax: +385 (51) 686166

www.intechopen.com

\section{InTech China}

Unit 405, Office Block, Hotel Equatorial Shanghai

No.65, Yan An Road (West), Shanghai, 200040, China

中国上海市延安西路65号上海国际贵都大饭店办公楼 405 单元

Phone: +86-21-62489820

Fax: +86-21-62489821 
(C) 2012 The Author(s). Licensee IntechOpen. This is an open access article distributed under the terms of the Creative Commons Attribution 3.0 License, which permits unrestricted use, distribution, and reproduction in any medium, provided the original work is properly cited. 